\title{
Recontextualizing the Case Study
}

\author{
James S. Cleveland, Sage College of Albany, USA
}

John A. MacDonald, State University of New York at Oswego, USA

\begin{abstract}
Case studies are very difficult to use with students who will not read them or whose reading skills are too poor to absorb the details of the case necessary to use it in a class discussion or paper. This paper explores a way to write cases that will engage such students, be memorable to them, and prompt lively discussion and achievement of learning goals. It is based on the work of Walter $J$. Ong and involves centering cases around a context with which the student can identify personally. The case was designed to facilitate ethical discussions in a senior finance course, but the techniques are applicable to any discipline at any level.
\end{abstract}

Keywords: finance; capital budgeting; net present value (NPV); internal rate of return (IRR); payback period; economic multiplier; downsizing; sustainability; risk; @RISK; ethical; social responsibility; rights; justice; utility; values; labor relations; stakeholder

\section{INTRODUCTION}

n 1982, in his seminal work Orality and Literacy, Walter J. Ong noted the development of what he called secondary orality. "This new orality," he noted, "has striking resemblances to the old. ..." (Ong 1982) One way in which secondary orality is similar to primary orality is that thought is situational rather than abstract; in other words, in a context familiar to the student's experience. Ong says that concepts "remain close to the living human lifeworld." (Ong 1982)

For those of us who are fully literate, firmly embedded in what Tom Pettitt of M.I.T. refers to as "the Gutenberg Parentheses," (Pettitt n.d.) words are reified. They are objects that lie unchanging and safe between the covers of books. Every time we open the book, the words will be there waiting for us exactly as they were before. It is the unchanging words themselves that become our context.

For the secondarily oral, words are not like this. They have grown up not with books, but with computers and multimedia presentations. As Marc Prensky (2009) has noted, they are "digital natives" while the rest of us are "digital immigrants." By the time they are 21, today's traditional-aged students have spent 10,000 hours playing video games, 20,000 hours watching television, and 10,000 hours talking on their cell phones. They have sent a quarter million e-mails but have devoted only 5,000 hours to reading. (Prensky 2001)

For them, words are evanescent things. They exist only so long as they are on the computer screen. Each time a web page is loaded, the words will be different. Indeed, for many self-refreshing pages, the words will be different if you happen to look away for a moment. For them, text does not possess the same solidity as it does for us who are firmly embedded in the world of literacy. Words in and of themselves do not provide context.

Thus, for many of our traditional-aged students - those who are secondarily oral - concepts are real only when they occur in a context or, as Ong puts it, when they are "close to the living human lifeworld." Concepts such as " 60 workers" are empty abstractions. The " 60 workers" have no faces, no names, no stories, no lives. They are not part of the students' "living human lifeworld." There are no consequences or interest involved in the situation for "60 workers".

For this reason, using case studies in Business Ethics and Finance courses has become very difficult. When "60 workers" doesn't really mean much, it is disarmingly easy to decide to lay them off. They are not real. They don't have names or faces or lives. They are just abstract numbers. The human context has been removed. 
There is a significant danger here, we believe. The next generation of business managers must be able to understand that workers are real people just as they are. They must be able to see beyond the numbers to the names, faces and lives their decisions will impact. Ways must be found to bring course material closer to the "living human lifeworld." We have called this process recontextualizing.

\section{RECONTEXTUALIZING}

The process is a simple one. We have abjured using "real life situations" for our case and, instead, crafted a fictional case in which there are people with names and lives and stories. We have attempted to include people of both genders and a variety of ages so every student can identify with at least one person. This makes the people in the case real to the student in ways that " 60 workers" cannot be real to them. In effect, instead of writing a case, we wrote a story that fit into the course where it would be used.

The plot involves a family in which both of the parents work for a large company in a small town. In addition there is another family, the father of which manages the local plant. He is asked to consider the advisability of a project in which new machinery would be purchased and a significant number of workers, including the parents in the family in the case, would lose their jobs. What recommendation should he make?

The case includes information about each member of both families --- how the adults met and married, where they come from initially, their hobbies and interests, etc. — and their children — their ages, school grades, academic and sports interests, career goals, etc. It includes information about the small town in which these families live. All of this provides "living human lifeworld" context to the case making it feel real and relevant to the students. The business decision must be made within a community context.

There is a financial dimension to the case as students must calculate the effects of purchasing the new equipment in terms of the net present value and internal rate of return for the project. They are also asked to consider the risk related to the estimated cash flows. But the students must then go beyond the numbers to the people involved. These are not just faceless, nameless "workers," but people with names and lives and children just like themselves. The case now has a context that makes it more real to the students.

\section{STUDENT RESPONSE}

The case was assigned to be read by students in a senior-level finance course taken by finance majors. The case was about three pages long. A spreadsheet of 20 years of (annuity) estimated cash flows was provided, as was the EXCEL-generated NPV and IRR. Students were encouraged to assess the risk of the positive NPV result using @RISK, a risk-assessment add-on to EXCEL.

The calculations of the net present value (NPV) and internal rate of return (IRR) were provided to the students on a spreadsheet and showed that buying the new equipment and laying off the workers would add a small amount of value to the stock of the corporation (between one and two million without risk consideration). Under ordinary circumstances students would have settled for that and recommended undertaking the project. But not this time.

Students identified so strongly with the characters in the case that they did not want to lay them off and began looking for arguments to support their position. These included the effects the layoff would have on the town and the community, management-labor relations, and the usual non-quantitative arguments used in business ethics courses. But in this case it also included looking for weaknesses in the financial analysis.

The @RISK software indicated through simulation that a probability that the NPV would be negative occurred 5 to 30 percent of the time, depending on the input distributions provided by students.

This is exactly what senior finance majors ought to be doing and what they ought to do as graduates when they are in positions to make decisions such as this. The student response was energetic, engaged and gratifying. 
Afterward, students were asked to submit an evaluation of the case in which they wrote about what they liked best about the case. Unprompted, most of the students wrote that they liked how real the case was, one noting it was just like the student's home town. A couple of students did not like the "recontextualizing" because it made the decision harder to make than with just numbers and had generated too much time in discussion/argument within the team! Instead of making the typical call with the positive NPV, all student teams rejected the project (to the faculty member's astonishment, who had previously seen MBA students accept a project that showed a positive NPV though the project had a $38 \%$ probability of failure.)

\section{CONCLUSION}

By providing a "living human lifeworld" context to the case rather than presenting it in the abstract but factual way most cases are written, it engaged the students' interest and inspired them to dig deeply into the data, to question the numbers, and to analyze the effects, both quantitative and non-quantitative, of the proposed action.

The same context could be extended into other cases in the same class or even across classes. Although we placed the case in a small rural town, it could be moved to a city which would change considerably the issues involved. Alternately, characters from the case could move to different locations and encounter different situations. Students might even be encouraged to write up their own cases involving the characters which could be used in the course in later semesters.

We believe that this case lends itself to both in-class and on-line treatment. Wikis could be provided so students could write the manager's recommendation or a news report about the situation and what effects it could have on the town. Discussion boards or blogs could be provided for students to discuss issues in the case. These are the most popular on-line learning environments (Baker, Matulich \& Papp, 2007). It would also work well with Eisner's "Team Challenge" technique in which teams of students compete with each other to present the best analysis/solution to a case and earn extra-credit points (Eisner 2007).

For those colleges and universities that have adopted Kaplan and Norton's Balanced Scorecard (1996) approach or van der Woerd and van den Brink's Responsive Business Scorecard (2004) approach as described by Sherman (2007), the case fits nicely into the models around which such programs are structured.

\section{AUTHOR INFORMATION}

James S. Cleveland earned his Bachelor's of Science degree in History and Classics at Allegheny College and his Masters of Management at Aquinas College. He has been teaching Marketing and Business Ethics at the Sage College of Albany since 1989. Prior to teaching, he served as the coordinator of employment and training programs for the Roman Catholic diocese of Grand Rapids earning recognition from the State of Michigan for operating the most efficient and effective programs receiving state funding. His research interests lie in the area of teaching the new generation of students.

John A. MacDonald teaches finance, risk management and insurance courses at the State University of New York at Oswego. He holds a Ph.D. in Finance from Virginia Tech, an MBA from Clarkson University, and a Bachelor's of Arts degree in Psychology/(Pre-Med) from the University of Vermont. He has published in a variety of financial journals on such topics as banking, IPO markets, market volatility, and market inefficiency. Prior to working in higher education, he was a production scheduler and inventory manager for a division of a multi-national forest products company.

\section{REFERENCES}

1. Baker, R., Matulich, E. and Papp, R. (2007). "Teach Me In the Way I Learn: Education And The Internet Generation," Journal of College Teaching and Learning. April 2007.

2. $\quad$ Eisner, S. P., (2007). "Click Here For Reality: Enhancing Student Engagement." Journal of College Teaching and Learning, January 2007. 
3. Kaplan, R. S. and Norton, D. P., (1996). The Balanced Scorecard: Translating Strategy into Action. Boston, Harvard Business School Press.

4. Ong., W. J. (1982) Orality and Literacy, The Technologizing of the Word. New York, Routledge.

5. Pettitt, T. (n.d.) Before the Gutenberg Parenthesis: Elizabethan-American Compatibilities. http://web.mit.edu/comm-forum/mit5/papers/pettitt_plenary_gutenberg.pdf.

6. $\quad$ Prensky, M. (2001). "Digital Natives, Digital Immigrants." On the Horizon. 9:5, October 2001.

7. Prensky, M. (2009). "H. Sapiens Digital: From Digital Immigrants and Digital Natives to Digital Wisdom," Innovate: A Journal of Online Education, February/March 2009, http://www.innovateonline.info/pdf/vol5_issue3/H._Sapiens_Digital-

8. From_Digital_Immigrants_and_Digital_Natives_to_Digital_Wisdom.pdf

8. Sherman, W. R. (2007). "In Search of an Integrative Theme for the Undergraduate Business Curriculum," Journal of College Teaching and Learning. December 2007.

9. Van der Woerd, F. \& van den Brink, T. (2004). "Feasibility of a Responsive Business Scorecard — A Pilot Study," Journal of Business Ethics. 55:173-186. 